\title{
ZNAKI BOSKIEJ RZECZYWISTOŚCI: \\ INTERPRETACJA I KRYTYKA KONCEPCJI TEISTYCZNYCH ZNAKÓW NATURALNYCH CHARLESA S. EVANSA*
}

\section{WPROWADZENIE}

Celem artykułu jest interpretacja oraz krytyka koncepcji „teistycznych znaków naturalnych", stworzonej przez amerykańskiego filozofa Charlesa Stephena Evansa i wyłożonej przede wszystkim w pracy Natural Signs and Knowledge of God: A New Look at Theistic Arguments (2010). „Teistyczne znaki naturalne" to charakterystyczne doświadczenia lub własności świata, które sprawiają, że jednostka, która ma te doświadczenia lub zetknie się z owymi własnościami świata, uzyskuje bezpośrednią świadomość rzeczywistości Boskiej i odczuwa impuls do tworzenia pewnych podstawowych przekonań na temat istnienia Boga i jego natury. Znaki umożliwiają w ten sposób uzyskanie bezpośredniego, naturalnego (niewymagającego wsparcia w postaci specjalnego objawienia) poznania Boga. Zdaniem Evansa klasyczne argumenty teologii naturalnej, mające na celu wykazanie istnienia Boga, są tak naprawdę próbą wyrażenia uzyskanego dzięki znakom poznania bytu absolutnego w postaci argumentów.

W pierwszej części artykułu dokonuję ekspozycji stanowiska Evansa, umieszczając je w szerszym kontekście próby stworzenia modelu „naturalnej wiedzy o Bogu". Następnie rozwijam dwie możliwe odpowiedzi na pytanie,

\footnotetext{
Dr StANiSŁaw RUCZAJ — adres do korespondencji - e-mail: stanislaw.ruczaj@gmail.com; ORCID: https://orcid.org/0000- 0003-4115-376X.

* Fragmenty artykułu zostały zaczerpnięte z mojej rozprawy doktorskiej Źródła wiary. O warunkach powstawania przekonań religijnych $w$ perspektywie analitycznej filozofii religii, napisanej pod opieką dr. hab. Sebastiana Kołodziejczyka i obronionej w październiku 2018 r. na Uniwersytecie Jagiellońskim.
} 
jak dokładnie działają teistyczne znaki naturalne. W trzeciej części artykułu wysuwam zarzuty wobec elementów analizowanej koncepcji.

\section{NATURALNE POZNANIE BOGA}

POPRZEZ TEISTYCZNE ZNAKI NATURALNE

Koncepcja teistycznych znaków naturalnych (dalej skrót: TZN) zostaje wprowadzona za pomocą eksperymentu myślowego (por. Evans 2010, 1317). Zadajmy sobie pytanie: gdyby faktycznie istniał dobry Bóg $^{1}$, który stworzył świat i któremu zależy na wejściu w relację ze swoimi stworzeniami (relację, której zwieńczeniem jest ich wieczne szczęście), jakiego rodzaju poznanie Boga byłoby dla nas możliwe? Evans argumentuje, że takie poznanie będzie cechować się trzema własnościami.

Po pierwsze, będzie miało charakter „naturalny”, tzn. będzie można je osiągnąc bez pomocy specjalnego objawienia. Takie poznanie musi zatem dotyczyć jakichś „ogólnie dostępnych cech świata naturalnego lub wspólnych ludzkich doświadczeń".

Po drugie, takie naturalne poznanie Boga powinno być powszechnie dostępne dla każdego, kto jest nim zainteresowany. Tę charakterystykę wyraża „zasada powszechnej dostępności” (Wide Accessibility Principle).

Po trzecie, naturalna wiedza o Bogu nie powinna narzucać się jednostce w natarczywy, nieodparty sposób, ale powinna zostawiać jej miejsce na podjęcie wyboru, czy chce uznać istnienie Boga, czy też nie. Tę własność naturalnej wiedzy o Bogu wyraża „zasada łatwiej odpieralności” (Easy Resistibility Principle).

Koncepcja Evansa ma stanowić wypełnienie naszkicowanego powyżej modelu naturalnego poznania Boga ${ }^{2}$. TZN to powszechnie dostępne typy ludzkich doświadczeń lub własności świata, które w szczególny sposób jednak bez przymusu — skłaniają ludzi, którzy mają doświadczenia tego typu lub stykają się z rzeczonymi własnościami świata, do tworzenia (uzasadnionych) przekonań o tym, że istnieje Bóg i że ma on pewne atrybuty. Przykładami TZN są: doświadczenie dobrego uporządkowania (,zaprojekto-

\footnotetext{
${ }^{1}$ „Bóg” jest tu pojmowany klasycznie - jako wszechmocny, doskonale dobry i wszechwiedzący byt osobowy. Por. Evans 2010, 13.

${ }^{2}$ Evans skupia się na filozoficznej analizie modelu. Odnosi się jednak także do badań nad naturalnością przekonań religijnych, prowadzonych w ramach kognitywnej nauki o religii — por. EVANS 2010, 39-42.
} 
wania”) wszechświata, które skłania do utworzenia przekonania o istnieniu inteligentnego projektanta owego wszechświata (ibidem, 98); doświadczenie przygodności, zagadkowości czy tajemniczości rzeczywistości (ibidem, 60) określa je jako doświadczenie „kosmicznego zachwytu”), które sugeruje jednostce istnienie bytu koniecznego, który w jakiś sposób rzeczywistość funduje; doświadczenie obligacji moralnej, które wskazuje na osobę, z której te obligacje wypływają i przed którą ludzie są odpowiedzialni (ibidem, 138); doświadczenie wewnętrznej wartości i godności istot ludzkich, które sugeruje, że istnieje ktoś, kto jest źródłem tej wartości (a osoby ludzkie są jego “obrazami”) (ibidem, 145-147).

Bardziej szczegółowo naturę i funkcję TZN można przedstawić, odnosząc je do szerszej kategorii znaków naturalnych - pojęcia, które Evans zaczerpnął z myśli szkockiego filozofa okresu Oświecenia, Thomasa Reida (ibidem, 27-34). Szkocki myśliciel twierdzi (w interpretacji Evansa), że znaki naturalne są czymś, przez co podmiot uzyskuje bezpośrednią świadomość tego, co znak oznacza. Takim znakiem w przypadku percepcji są wrażenia (sensations), przez które ludzie bezpośrednio postrzegają przedmioty fizyczne. Innym przykładem znaku naturalnego jest zachowanie i mimika innych ludzi, przez które bezpośrednio odczytujemy ich stany mentalne. Udostępniając świadomości rzeczywistość, którą oznaczają, znaki „sugerują” jednostce — z różną siłą — przekonania na temat tejże rzeczywistości. Te same funkcje spełniają TZN: kontakt $\mathrm{z}$ teistycznym znakiem naturalnym daje jednostce bezpośrednią świadomość Boga (świadomość de re) oraz „sugeruje”, „podsuwa” jej pewne przekonania dotyczące jego istnienia i natury.

Znaki mają charakter naturalny, ponieważ związek między znakiem a tym, co ów znak oznacza, nie jest konwencjonalny (jak w przypadku znaków językowych — por. West i Pelser 2015, 294): w naszej naturze leży, by odczytywać je w taki, a nie inny sposób. Siła, z jaką znaki „sugerują” nam przyjęcie pewnych przekonań na temat obiektów oznaczanych, różni się przy tym w zależności od typu znaku. W przypadku percepcji mamy mniejsze pole do manewru niż w przypadku odczytywania cudzych stanów mentalnych (jeśli wiemy, że dana osoba udawała, że ma pewne stany mentalne w przeszłości, nasza skłonność, by brać za dobrą monetę jej mimikę i zachowanie, może ulec osłabieniu) (Evans 2010, 34). W przypadku TZN mamy wrodzoną dyspozycję, by nadawać im konkretną — w tym wypadku religijną — interpretację (znaki „sugerują” nam, by odczytać je w konkretny sposób). To, że mamy taką dyspozycję, nie jest przypadkowe: rzeczone typy doświadczeń i własności świata zostały stworzone przez Boga po to, by funkcjo- 
nowały jako znaki (ibidem, 35). Sugestia płynąca od znaku może jednak stosunkowo łatwo zostać zignorowana lub zmodyfikowana (ibidem, 34). Mogą się do tego przyczynić różne czynniki, np. opór jednostki, która z jakiegoś powodu (na przykład grzesznego pragnienia niezależności wobec Boga) nie chce utworzyć przekonań o istnieniu Boga i jego naturze. Niechęć taka może jednak brać się również stąd, że inne przekonania jednostki nie zgadzają się z sądami teizmu. Może to wynikać zarówno z wpływu, jaki miało środowisko jednostki na ukształtowanie jej przekonań, jak i z jej własnej refleksji.

W większości przypadków, w których jednostka styka się ze znakiem naturalnym, funkcjonuje on jako znak, tzn. jest transparentny. W takich przypadkach uwaga podmiotu kieruje się na przedmiot oznaczany, a nie na sam znak. W szczególnych okolicznościach możemy jednak także skoncentrować się na samym znaku (na przykład, zarzucając komuś, że wprowadził nas w błąd co do swojego samopoczucia, wskazujemy na to, że „udawał" pewne stany mentalne - np. płakał, jakby z bólu; ibidem, 34). Tak samo jest w przypadku TZN: choć zazwyczaj uwaga podmiotu przenosi się od razu na obiekt oznaczany (Boga), to podmiot może skoncentrować się na samym znaku. Zdaniem Evansa właśnie z tym mamy do czynienia w przypadku szeregu argumentów za istnieniem Boga, które wysuwali filozofowie uprawiający teologię naturalną. $\mathrm{Na}$ przykład $\mathrm{w}$ argumencie $\mathrm{z}$ przygodności za istnieniem bytu koniecznego doświadczenie przygodności nie funkcjonuje jako znak - nie odsyła bezpośrednio do rzeczywistości bytu koniecznego ale staje się przesłanką argumentu (na przykład w postaci tezy „rzeczywistość ma charakter przygodny”) (por. Evans 2011, 48). Jednocześnie wartość poznawcza znaku pozostaje niezależna od wartości poznawczej argumentu (por. Evans 2010, 2); osoba, która odrzuciła dany argument teistyczny, wciąż może mieć bezpośredni dostęp do Boga, który daje jej znak. Taka jednostka wciąż może odczuwać „napór” znaku, który leży u podstawy argumentu (ibidem, 2, 64). To właśnie stąd bierze się ciągły powab argumentów teologii naturalnej: nawet ich krytycy przyznają, że rozumowania te dotykają czegoś w naszym doświadczeniu, co faktycznie zdaje się „łączyć” nas z rzeczywistością Boga.

Wreszcie trzeba zauważyć, że Reidowskie znaki naturalne dostarczają wiedzy, tzn. prawdziwych przekonań, które posiadają uzasadnienie. Evans proponuje, by w przypadku przekonań wytworzonych przez TZN mówić o uzasadnieniu $\mathrm{z}$ perspektywy internalistycznej (w której przekonanie jest uzasadnione, jeśli racje dla tego przekonania są czymś, z czego podmiot 
żywiący przekonanie zdaje sobie sprawę) lub eksternalistycznej (w której podstawą uzasadnienia przekonania są obiektywne fakty dotyczące sposobu, w jaki ono powstało) (ibidem, 173). W tej pierwszej perspektywie, przekonania wytworzone dzięki TZN są uzasadnione, ponieważ jednostce, która styka się z TZN, wydaje się, że jest tak, jak głosi przekonanie teistyczne, do którego utworzenia popycha ją kontakt ze znakiem³ ${ }^{3}$ „Gdy doświadczają oni [ludzie] znaków, wydaje się im, że jest tak, że Bóg stoi za tymi znakami jako ten, na którego one wskazują" (ibidem, 184). W perspektywie eksternalistycznej przekonania uzyskane dzięki TZN są uzasadnione, ponieważ mechanizm ich wytwarzania - wrodzona dyspozycja, która reaguje na zetknięcie się ze znakami - działa w sposób obiektywnie rzetelny (ostatecznym gwarantem tej rzetelności jest Bóg, który wyposażył w nią ludzi i nie jest zwodzicielem) (ibidem, 173).

TZN spełniają zatem wszystkie trzy własności modelu „naturalnej wiedzy o Bogu”. Po pierwsze, są powszechnie dostępne: chodzi o doświadczenia czy cechy świata, które są dostępne niezależnie od kultury i epoki, w jakiej żyją ludzie. Po drugie, są naturalne $\mathrm{w}$ tym sensie, że nie wymagają specjalnego objawienia. Po trzecie, są łatwo odpieralne: dyspozycja do teistycznej interpretacji znaków naturalnych może zostać stosunkowo łatwo zmodyfikowana. Wreszcie umożliwiają poznanie Boga, tzn. wytworzenie prawdziwych przekonań, które są uzasadnione.

\section{JAK DZIAŁAJĄ TEISTYCZNE ZNAKI NATURALNE?}

W koncepcji Evansa teistyczne znaki naturalne (1) dają jednostce bezpośrednią świadomość Boga i (2) umożliwiają tworzenie przekonań de re na jego temat. Co jednak może znaczyć, że znaki dają jednostce świadomość Boga? Evans nie rozwija tej kwestii. W tej sekcji chciałbym rozważyć dwie możliwe odpowiedzi na to pytanie. Opierają się one na rozróżnieniu między percepcją pośrednią (indirect perception) i pośrednią identyfikacją percepcyjną (indirect perceptual recognition), wprowadzonym przez Williama Alstona (1991). Zgodnie z pierwszą interpretacją teistyczne znaki naturalne umożliwiają jednostce pośrednią percepcję Boga i wytworzenie przekonań na jego temat. Ta interpretacja, jak sądzę, jest najbliższa intencjom samego

\footnotetext{
${ }^{3}$ Evans odwołuje się tutaj do zasady konserwatyzmu fenomenalistycznego, która głosi, że posiadam, przynajmniej prima facie, rację dla przekonania, że $p$, jeśli wydaje mi się, że $p$ (it seems to me that $p$ ) - por. Evans 2010, 181.
} 
Evansa. Zgodnie z drugą interpretacją teistyczne znaki naturalne nie umożliwiają, co prawda, percepcji Boga, ale umożliwiają pośrednią identyfikację Boga dzięki danym w doświadczeniu wskazówkom czy też śladom jego obecności, którymi są właśnie owe znaki. Choć interpretacja ta wymaga pewnej modyfikacji koncepcji teistycznych znaków naturalnych, to wydaje się bardziej zgodna z częścią danych obserwacyjnych, które Evans przywołuje na poparcie swojej teorii.

W ujęciu Alstona, z percepcją pośrednią mamy do czynienia wtedy, gdy „[...] postrzegamy $\mathrm{X}$ na mocy postrzegania czegoś innego, Y” (Alston 1991, 21). Mówiąc inaczej, obiekt percepcji postrzegany jest poprzez inny obiekt. Przykładami percepcji pośredniej są: obserwacja planety przez teleskop, oglądanie kogoś w telewizji czy w lustrze, słyszenie czyjegoś głosu przez telefon. Zdaniem Alstona pewne doświadczenia religijne można analizować jako sytuacje pośredniego postrzegania Boga - chodzi, na przykład, o doświadczenie Boga w pięknie przyrody albo w drugim człowieku. Wiele uwag Evansa sugeruje, że o działaniu TZN należy myśleć właśnie w taki sposób. Oto przykład:

Jeżeli [...] Bóg dał nam naturalną tendencję, by postrzegać go poprzez nasze doświadczenie obowiązku, to istnieje rodzaj siły, która cechuje to doświadczenie, której nie da się całkiem uchwycić w argumencie. (Evans 2011, 51) ${ }^{4}$.

Doświadczenie obligacji moralnej jest tutaj tym, „przez co” postrzegany jest Bóg. Stosując schemat Alstona, „X” jest w tym wypadku Bogiem, a „Y” - doświadczeniem obowiązku. W przypadku innych TZN jednostka postrzega Boga poprzez doświadczenie przygodności wszechświata, poprzez doświadczenie dobrego uporządkowania rzeczywistości czy też poprzez doświadczenie godności innych osób.

Warto tu poczynić dwie dodatkowe uwagi. Ujęcie Alstona dopuszcza możliwość percepcji obiektu, która nie jest uświadomiona, tzn. nie wiąże się z poprawną identyfikacją obiektu postrzeganego (por. ALSTON 1991, 11-12). Evans wskazuje, że dostęp do Boga za pośrednictwem TZN nie musi wiązać się z poprawną identyfikacją Boga jako Boga. Mówiąc inaczej, jedną rzeczą jest to, że znak daje nam dostęp do pewnej rzeczywistości, inną natomiast to, jak ta rzeczywistość zostanie zinterpretowana.

${ }^{4}$ „If [...] God has given us a natural tendency to perceive him through our experience of obligation, then there will be a kind of force in this experience that is not completely captured by the argument”. 
Po drugie, stwierdzenie Evansa, że znaki pozwalają na bezpośrednie doświadczenie Boga, nie stoi bynajmniej w sprzeczności z uznaniem, że mamy tu do czynienia $\mathrm{z}$ percepcją pośrednią w sensie Alstona, ponieważ filozofowie ci używają kategorii pośredniości w innym sensie: Evans mówi o bezpośredniości psychologicznej (znak jest dla nas transparentny, tj. nasza uwaga nie zatrzymuje się na samym znaku, ale na obiekcie, który oznacza), podczas gdy Alston o pośredniości przyczynowej, tzn. o tym, że w łańcuchu kauzalnym między obiektem (tu: Bogiem) a podmiotem postrzegającym znajduje się coś jeszcze (tu: sam znak) (por. Evans 2011, 42-43).

Percepcyjna interpretacja TZN pozwala także rozwinąć poruszoną już kwestię siły oddziaływania, jaką mają argumenty teologii naturalnej. Argumenty te pozostają tak przekonujące, ponieważ u ich podstaw stoi percepcja Boskiej rzeczywistości. Gdy jednostka postrzega Boga za pośrednictwem TZN, uświadamia sobie z dużą mocą, że istnieje związek między znakiem a istnieniem Boga. Argument filozoficzny jest następnie próbą wyrażenia tego związku w postaci rozumowania.

Alternatywna interpretacja ${ }^{5}$ głosi, że tworzenie przekonań teistycznych w wyniku zetknięcia się ze znakami dokonuje się dzięki pośredniej identyfikacji percepcyjnej. Według Alstona z taką identyfikacją mamy do czynienia, gdy na podstawie percepcji jednego obiektu domniemywa się obecność drugiego obiektu (drugi zaś obiekt nie jest przy tym postrzegany). Mówiąc słowami Alstona, percepcyjnie identyfikuję pośrednio pewne X, gdy „traktuję coś jako znak lub wskazówkę X, ale nie widzę samego X”. Przykładem jest sąd o treści: „przed chwilą przelatywał nad nami samolot”, utworzony w wyniku spostrzeżenia smug kondensacyjnych na niebie. Rozróżnienie między percepcją pośrednią a pośrednią identyfikacją percepcyjną można też wyrazić w kategoriach dystynkcji między „widzeniem” a ,widzeniem, że". W przykładzie z samolotem nie mogę powiedzieć, że widzę samolot, ale mogę już stwierdzić, że widzę, że samolot przeleciał (por. WEST i Pelser 2015, 296). Zastanówmy się nad tym, jak w takim ujęciu wygląda funkcjonowanie TZN. Jako przykład niech posłuży wypowiedź Evansa opisująca doświadczenie „kosmicznego zachwytu”:

\footnotetext{
${ }^{5} \mathrm{Za}$ interpretacją teistycznych znaków naturalnych jako percepcji pośredniej w sensie Alstona opowiadają się West i Pelser (2015). Rozważają oni, co prawda, możliwość zinterpretowania działania znaków jako pośredniej identyfikacji percepcyjnej, ostatecznie jednak na nią się nie decydują i nie omawiają jej szerzej.
} 
[...] w naszym doświadczeniu kosmicznego zachwytu, w którym postrzegamy świat jako przygodny, implicite zawiera się uchwycenie idei, że może być inny rodzaj istnienia, rzeczywistość, która istnieje w głębszy i trwalszy sposób, niż rzeczy, które nas otaczają. [...] [Doświadczenie to] [u]mieszcza w naszych umysłach idę 'bytu koniecznego'. Sugeruje nam jednak również, być może niezbyt jasno i stanowczo, że wszechświat musi w jakiś sposób spoczywać na tym innym rodzaju rzeczywistości”. (Evans 2010, 63) .

Sądzę, że fragment ten mówi, iż podmiot, który doświadcza kosmicznego zachwytu, nie postrzega Boga w żaden sposób (nawet pośrednio). Nie jest tak, że doświadczenie „kosmicznego zachwytu” jest „lustrem”, w którym odbija się byt konieczny. Podmiot postrzega natomiast przygodność czy „stworzoność" świata, i to postrzeżenie wiąże się z natychmiastowym uchwyceniem idei bytu koniecznego oraz sugestią, by podmiot uznał za prawdziwy sąd, że rzeczywistość w jakiś sposób zależy od owego bytu koniecznego. Sam byt konieczny jest zatem jedynie domniemywany, identyfikowany pośrednio, niczym samolot identyfikowany jest po śladach na niebie (przekonanie o treści „istnieje coś koniecznego, co utrzymuje ten świat w istnieniu” odpowiada tu przekonaniu o treści „przeleciał samolot, który zostawił te smugi"). Podobnie, jak w przypadku poprzedniej interpretacji, należy rozróżnić pośredniość psychologiczną i kauzalną. Identyfikacja Boga ma charakter pośredni w tym drugim sensie: żeby zidentyfikować Boga, muszę doświadczyć wpierw czegoś różnego od Boga, z czym Bóg jest w jakiś sposób powiązany. Proces tej identyfikacji ma jednak charakter bezpośredni psychologicznie, co znaczy, że samo doświadczenie od razu, bez przeprowadzenia rozumowania, wiąże się z identyfikacją jego Boskiego źródła.

Również inne TZN można zinterpretować w kategoriach pośredniej identyfikacji percepcyjnej. Każdy ze znaków odsyła podmiot do idei czegoś bardziej fundamentalnego, co jest ściśle ze znakiem powiązane. Na przykład doświadczenie odpowiedzialności moralnej sugeruje istnienie kogoś, kto może być źródłem obligacji moralnej, ale to doświadczenie niekoniecznie jest medium, przez które ta osoba jest postrzegana. W omawianej interpretacji to właśnie to ścisłe powiązanie odpowiada za „moc" znaku, który „skłania” czy „domaga się" od podmiotu utworzenia przekonania nawet wówczas, gdy

6, ,...] implicit in our experience of cosmic wonder, in which we perceive the world as contingent, is a grasp of the idea that there could be a different manner of existing, a reality that has a deeper and firmer grip on existence than the things we see around us. [...] It puts the idea of a 'necessary being' in our minds. However, it also suggests to us, perhaps somewhat vaguely and tentatively, that the universe must somehow rest on this different kind of reality". 
argumenty teologii naturalnej, będące wyrazami odpowiedniego znaku, zostaną odrzucone (por. Evans 2011, 46-48).

Wspomniałem już, że choć powyższa interpretacja działania TZN ma pewne oparcie w przytaczanych przez Evansa przykładach, to jednak nie w pełni odpowiada temu, jak on sam charakteryzuje działanie znaków. Wydaje się bowiem, że znak operujący na zasadzie pośredniej identyfikacji percepcyjnej nie daje jednostce bezpośredniej świadomości Boga, ale raczej czegoś, co (tylko) odsyła jednostkę do Boga, i skłania ją do uznania pewnych sądów na jego temat.

\section{KRYTYKA ZASADY ŁATWEJ ODPIERALNOŚCI}

Niektóre aspekty koncepcji Evansa budzą wątpliwości. Mój pierwszy zarzut dotyczy racji, jaka stoi za zasadą łatwej odpieralności.

W pierwszej części tego artykułu zwróciłem uwagę, że dyspozycja do teistycznego odczytywania TZN może ulec modyfikacji pod wpływem różnych czynników. Koncepcja TZN realizuje w ten sposób jeden z istotnych elementów modelu naturalnego poznania Boga, jakim jest zasada łatwej odpieralności. Głosi ona, że naturalna wiedza o Bogu nie powinna narzucać się jednostce w natarczywy, nieodparty sposób, ale powinna zostawiać jej miejsce na podjęcie wyboru w kwestii tego, czy przyjmie istnienie Boga, czy też je odrzuci. Dla oceny tej zasady ważne jest zrozumienie, jaka racja stoi za jej wprowadzeniem. To, że skłonność jednostki do teistycznej interpretacji znaków stosunkowo łatwo może ulec modyfikacji z powodu różnych czynników, jest częścią Boskiego planu. Jeżeli kontakt jednostki z TZN nieodmiennie i nieodparcie sprawia, że tworzy ona przekonania teistyczne (istnienie Boga jest dla niej oczywiste), to zostaje ona pozbawiona wyboru w kwestii przyjęcia lub odrzucenia Boga. W rezultacie wielu ludzi służy mu z niewłaściwej motywacji - z powodów egoistycznych czy oportunistycznych zamiast $\mathrm{z}$ miłości. Miłość wymaga zatem epistemicznego dystansu. Z tego względu Bóg dopuszcza, by rozmaite czynniki mogły modyfikować ludzką dyspozycję do odczytywania znaków; same znaki również dopuszczają wiele możliwych odczytań:

By dać takim ludziom [którzy chcieliby żyć bez Boga] tę możliwość, Bóg musi sprawić, by świadectwa, jakie dostarcza na rzecz swojego istnienia, były mniej niż w pełni przekonujące. Może to być, na przykład, taki typ świadectw, który 
wymaga interpretacji i zawiera w sobie wystarczająco dużo wieloznaczności, że może być interpretowany na więcej niż jeden sposób. (Evans 2010, 15) ${ }^{7}$.

Uzasadnienie Evansa dla zasady łatwej odpieralności jest wątpliwe z czterech powodów.

Po pierwsze, trzeba stwierdzić, że niektórzy już teraz służą Bogu z lęku przed karą czy z pragnienia nagrody, i bez poczucia radości, chociaż istnienie Boga nie jest dla nich bynajmniej oczywiste; wystarczy, że istnienie Boga jawi się im tylko jako rozsądna możliwość. Gdyby Bogu faktycznie zależało na tym, by ludzie nie służyli mu z oportunistycznych pobudek, to uczyniłby swoje istnienie raczej jeszcze bardziej niepewnym — do tego stopnia, że ludzie po prostu przestaliby uznawać oportunizm religijny za opłacalny.

Po drugie, scenariusz, w którym TZN działają w sposób nieodparty, nie musi prowadzić do oportunizmu $\mathrm{w}$ relacji z Bogiem. Oczywistość istnienia Boga może wywołać u kogoś reakcję lęku (por. Jk 2,19). Inną możliwością jest bunt. Ktoś, dla kogo istnienie Boga jest jasne, może mimo to walczyć z Bogiem czy też mu się sprzeciwiać. Przypomnijmy tylko postać Iwana Karamazowa, który, co prawda, uznawał istnienie Boga, ale - wobec ogromu zła w świecie - zwracał mu „bilet wejścia” do nieba (por. Dostojewski 1913, 354).

Po trzecie, trzeba zauważyć, że ludzie nie zawsze potrafią rozpoznać swój (obiektywny) interes, a gdy już go rozpoznają, to nie zawsze działają zgodnie z nim. To, że istnienie Boga będzie dla nich oczywiste, nie oznacza więc, że uznają oni, że służba Bogu jest najlepszym, co mogą zrobić, albo, gdy dojdą jednak do takiego wniosku, że faktycznie będą żyli zgodnie z nim.

Po czwarte, wydaje się, że istnieje taka grupa ludzi, którzy boją się zaangażować w życie religijne dlatego, że świadectwa na rzecz sądów teistycznych są dla nich niewystarczające. Reprezentują oni stanowisko w ramach aksjologii poznania, które Włodzimierz Galewicz, komentując znany esej Williama Jamesa The Will to Believe (pol. Prawo do wiary), nazywa „bojaźliwym” czy „ostrożnym” (por. GALEWICz 1996, 17). Osoby takie kierują się regułą, która nakazuje im minimalizować fałsz w ich przekonaniach. W świetle takiej aksjologii uznanie sugerowanych przez TZN sądów religijnych może wydawać się niewłaściwe, dopóki nie pojawią się nowe, lepsze świadectwa na rzecz ich prawdziwości. W sytuacji, gdy TZN są jednoznaczne i sprawiają, że istnienie Boga jest oczywiste dla każdego, kto się z nimi zetknie, ta przeszkoda w utworzeniu przekonań teistycznych znika.

${ }^{7}$ „To allow such people this option, it is necessary for God to make the evidence he provides for himself less than fully compelling. It might, for instance, be the kind of evidence that requires interpretation, and include enough ambiguity that it can be interpreted in more than one way". 
Racje wysuwane za zasadą łatwej odpieralności są zatem wątpliwe. Gdyby TZN były jednoznaczne, a dyspozycja do ich odczytywania niepodatna na modyfikacje, ludzie wciąż mieliby przestrzeń, by żyć tak, jakby Boga nie było, albo zbuntować się przeciw niemu. Nie jest też powiedziane, że zwiększyłaby się liczba religijnych oportunistów. Co więcej, ludzie, którzy do tej pory obawiali się zaangażować religijnie, sądząc, że świadectwa na rzecz teizmu są nieprzekonywujące, zyskaliby powód, by wejść w relację ze swoim Stwórcą. Biorąc to pod uwagę, zwolennik stanowiska Evansa powinien poszukać innych, lepszych argumentów na rzecz tezy, że Bóg pragnąłby, aby znaki jego istnienia były wieloznaczne, a dyspozycja do ich teistycznej interpretacji plastyczna. ${ }^{8}$

\section{„ATEISTYCZNE ZNAKI NATURALNE” I BÓG-ZWODZICIEL}

Problematyczna okazuje się jednak nie tylko sama niejednoznaczność TZN. W spektrum ludzkich doświadczeń znajdują się bowiem również takie, które działają w sposób analogiczny do TZN, ale skłaniają osoby, które mają te doświadczenia, do tworzenia przekonań o tym, że Boga nie ma. Za Sarah Adams i Jonem Robsonem (2016) określam je jako ,ateistyczne znaki naturalne" (AZN). Koncepcja ta posłuży mi w tym paragrafie jako punkt wyjścia do sformułowania nowej linii krytyki stanowiska Evansa.

Jako przykłady AZN Adams i Robson podają doświadczenie wrogości i niegościnności świata, doświadczenie obojętności świata wobec naszych potrzeb czy doświadczenie absurdu (Adams i RoBson 2016, 60-61). Argumentują, że - jeżeli ateizm jest prawdziwy - te typy doświadczeń dają jednostce bezpośrednią psychologicznie świadomość rzeczywistości, która ma pewne cechy, jakich by nie posiadała, gdyby Bóg istniał (na przykład jest

\footnotetext{
${ }^{8}$ Inna linia krytyki stanowiska Evansa może polegać na wykazywaniu, że Bóg, który dopuszcza wieloznaczność świadectw na rzecz swojego istnienia, nie jest kochający. Prowadzi to nas do problemu tzw. Boskiego ukrycia (Divine hiddenness), wyrażonego w znanym argumencie przez Johna Schellenberga (2015). Schellenberg dowodzi, że miłość Boga do wszystkich stworzonych osób przejawiałaby się z konieczności $\mathrm{w}$ jego trwałej otwartości na wejście $\mathrm{z}$ nimi $\mathrm{w}$ odwzajemnioną, świadomą relację. Warunkiem wejścia w taką relację — po stronie stworzonych osób — jest zaś to, że żywią one przekonanie o istnieniu Boga. Ponieważ jednak wiele osób, bez własnej winy, nie ma takiego przekonania, to wynika stąd, że nie ma Boga. W świetle tego argumentu, niejednoznaczność teistycznych znaków naturalnych może zostać potraktowana jako forma ukrywania się Boga, z czego można próbować wyciągać ateistyczne wnioski. Evans szeroko polemizuje z argumentem Schellenberga (por. szczególnie Evans 2010, r. 6). Nie zamierzam tu jednak rozwijać tego wątku wystarczy mi podważenie przedstawionych racji stojących za zasadą łatwej odpieralności.
} 
niegościnna dla człowieka), oraz skłaniają ją do utworzenia przekonania o nieistnieniu Boga. Można tu także wymienić doświadczenie zła: Jerome Gellman (1992) opisuje doświadczenia, w których podmiotowi „manifestuje się" nieistnienie Boga ${ }^{9}$. Podobieństwa między AZN a TZN można mnożyć: tak jak argumenty teologii naturalnej próbują wyrazić pewne doświadczenia, które pełnią rolę znaków Boskiej rzeczywistości, tak też argumenty „ateologii" (por. Plantinga 2000, 459) próbują wyrazić w formie rozumowań owe doświadczenia, które funkcjonują jako znaki Boskiego nieistnienia. Co więcej, przekonania utworzone dzięki AZN mają uzasadnienie prima facie nawet w sytuacji, w której argumenty wysuwane na poparcie tych przekonań okazują się niekonkluzywne (por. Gellman 1992, 216).

Scenariusz AZN można próbować podważyć, argumentując, że do tego, by coś funkcjonowało jako znak naturalny, potrzebne jest, by ktoś nadał mu taką funkcję. W ujęciu Evansa TZN zostały wszak stworzone przez Boga właśnie po to, by działać jako znaki jego istnienia. Co więcej, funkcjonowanie znaków naturalnych zakłada jakiś rodzaj powiązania przyczynowego między znakiem a tym, co oznaczane (na przykład obiektem fizycznym i wrażeniami zmysłowymi tego obiektu, mimiką i stanami mentalnymi - por. Evans 2010, 3436), trudno jest zaś wyobrazić sobie, w jaki sposób - przy założeniu prawdziwości ateizmu - nieistniejący byt może być powiązany przyczynowo z czymkolwiek. W odpowiedzi Adams i Robson wskazują, że szeroka kategoria znaku naturalnego, którą posługuje się Evans, nie wymaga odwołania do Boga i jego intencji; pewne obiekty, jak choćby właśnie wrażenia zmysłowe czy mimika, funkcjonują jako znaki naturalne niezależnie od tego, czy ktoś (Bóg) zadecydował, by tak właśnie funkcjonowały (por. ADAMs i RoBSon 2016, 61). W odpowiedzi na drugi zarzut autorzy stwierdzają, że członem relacji przyczynowej w omawianych przypadkach nie jest byt nieistniejący, ale raczej rzeczywistość, która ma pewne cechy, ponieważ Bóg nie istnieje (zdaniem Gellmana osoby, które doświadczają pewnych rodzajów zła, postrzegają w tym złu, że rzeczywistość jest „bez-bożna, pozbawiona Boga” [Godless, without a God] — por. Gellman 1992, 213). Takie relacje przyczynowe można wyrazić za pomocą okresów kontrfaktycznych (ADAMs i RoBSON 2016, 61), na przykład: „gdyby Bóg istniał, to rzeczywistość nie byłaby absurdalna" itd. Nie ma zatem powodów, by a priori wykluczyć możliwość istnienia ateistycznych znaków naturalnych ${ }^{10}$.

\footnotetext{
${ }^{9}$ Szerzej tę teorię analizuję w RUCZAJ 2017, 7-20.

${ }^{10}$ AZN w ujęciu, jakie prezentują Adams i Robson, działają zatem na zasadzie pośredniej identyfikacji percepcyjnej: percepcja pewnego obiektu (na przykład chaosu świata) służy jako podstawa
} 
Jakie wnioski można wyciągnąć z powyższych analiz?

1. Jak wskazują Adams i Robson, przy założeniu prawdziwości teizmu TZN dają ludziom wiedzę o Bogu, a przy założeniu prawdziwości ateizmu - AZN dają ludziom wiedzę o jego nieistnieniu. Na tej podstawie, autorzy argumentują, że między TZN i AZN zachodzi równoważność epistemiczna (por. AdAms i Robson 2016, 67). Można także mówić o pewnej równoważności epistemicznej AZN i TZN, jeśli przyjmiemy przywołane wcześniej internalistyczne kryterium uzasadnienia. Jednostce, która utworzy przekonanie teistyczne w wyniku kontaktu z TZN, wydaje się, że jest tak, jak mówi jej przekonanie. Podobnie: jednostce, która utworzy przekonanie ateistyczne w wyniku kontaktu z AZN, wydaje się, że jest tak, jak mówi jej przekonanie. $\mathrm{W}$ obydwu przypadkach kontakt $\mathrm{z}$ ateistycznymi lub teistycznymi znakami naturalnymi dostarcza internalistycznie pojmowanego uzasadnienia prima facie dla utworzonych przekonań.

2. Mamy do czynienia z całym spektrum własności świata i doświadczeń, z których jedne zdają się faworyzować teizm, inne zaś ateizm. Oznacza to, że ludzie będą skłonni do tworzenia przekonań teistycznych lub ateistycznych w zależności od tego, z którymi elementami spektrum będą się stykać. Być może nawet jedna i ta sama osoba będzie miała czasem skłonność do uznania sądu o istnieniu Boga, a innym razem do uznania negacji tego sądu. Fakt, że w naszym doświadczeniu i w rzeczywistości, która nas otacza, znajdują się rzekome ${ }^{11}$ AZN, wydaje się jednak niespodziewany, jeżeli założymy, że świat został stworzony przez kochającego Boga, który pragnie nawiązać relację ze swoimi stworzeniami, dla dobra tych stworzeń (por. Evans 2010,13). Okazuje się bowiem, że pewne elementy tego świata, systematycznie wprowadzają ludzi w błąd co do istnienia jego stwórcy. Jest to niespodziewane nawet $\mathrm{z}$ perspektywy ludzi, którzy już $\mathrm{w}$ istnienie tego stwórcy wierzą (a zatem nie przyznają AZN statusu autentycznych znaków naturalnych). Wystarczy, że zauważą oni, że inni ludzie zostali w ten sposób wprowadzeni w błąd w kwestii istnienia Boga. Mogą wówczas zasadnie zapytać, czy Bóg, który stworzył taką rzeczywistość, jest faktycznie dobry, a nie jest, na przykład, zwodzicielem, w duchu możliwości, którą rozważa Kartezjusz w pierwszej z Medytacji. ${ }^{12}$

do identyfikacji pewnego faktu (tu: nieistnienia Boga). W przypadku teorii Gellmana należy mówić o percepcji pośredniej: tym, co postrzegane w doświadczeniu zła, jest nieistnienie Boga.

11 „Rzekome” z perspektywy zwolennika stanowiska Evansa.

12 „Lecz może jednak Bóg nie chciał, bym był łudzony w taki sposób, skoro przecież mówi się o Bogu, że jest w najwyższym stopniu dobry? Jednakże gdyby sprawianie, abym się mylił wciąż, 
Zwolennik Evansa mógłby odpowiedzieć, że to, iż pewne doświadczenia powodują, że niektórzy tworzą przekonania o nieistnieniu Boga, nie jest winą Boga, ale tych ludzi. W wyniku indywidualnych, zawinionych deficytów moralnych albo odziedziczonej słabości (grzech pierworodny) dokonują oni nadinterpretacji swoich doświadczeń i tworzą przekonania ateistyczne. Taka odpowiedź - nieżyczliwa wobec ateistów ${ }^{13}$ - jest jednak problematyczna. Jeżeli Bóg istnieje i jest stwórcą świata, to sama zależność między takim indywidualnym lub odziedziczonym deficytem a skłonnością do nadinterpretacji pewnych doświadczeń jest czymś zależnym od Boga. Można łatwo sobie wyobrazić, że Bóg stwarza taki świat, w którym zależności tej nie ma i deficyty moralne i duchowe mają całkiem inne konsekwencje, jeśli chodzi o to, jakie przekonania tworzy dotknięta nimi jednostka. Jeżeli przyjmiemy, że Bogu faktycznie zależy na tym, by ludzie go poznali i weszli z nim we właściwą relację, to mamy tym samym powód, by przypuszczać, że Bóg stworzyłby właśnie taki — inny — świat.

Nie zadziała także kontrargument, że istnienie takich zwodniczych doświadczeń, które sugerują ludziom nieistnienie Boga, jest ceną ludzkiej wolności. W takim ujęciu, istnienie rzekomych AZN — tak jak omówiona już wcześniej niejednoznaczność TZN — jest warunkiem tego, że istnienie Boga nie jest dla ludzi oczywiste, nie przytłacza ich. Ryzyko, że niektórzy utworzą przekonanie, że Boga nie ma, w rezultacie doświadczenia zła, chaosu czy wrogości świata, jest zatem kosztem, który Bóg gotów jest ponieść, by nie odbierać im cennej autonomii. Taka odpowiedź odwołuje się jednak ponownie do zasady łatwej odpieralności. Jak starałem się pokazać, wysunięte za tą zasadą racje są słabe, ta linia obrony pozostaje zatem zamknięta dla zwolennika stanowiska Evansa, dopóki nie znajdzie on racji lepszych. Można także, na marginesie, zauważyć, że do tego, by istnienie Boga nie było dla ludzi przytłaczające, wystarczy, że TZN są niejednoznaczne; nie potrzeba, by istniały jeszcze jakieś inne, w szczególny sposób popychające do przyjęcia ateizmu doświadczenia.

kłóciło się z dobrocią Boga, to przecież byłoby z nią sprzeczne i to, aby pozwalał mi mylić się choćby tylko czasami, a przecież nie mogę wątpić, że właśnie na to pozwala" (KARTEZJUSz 2006 [1647], 31).

${ }^{13}$ Nieżyczliwość takiej postawy ma znaczenie zwłaszcza w sytuacji debaty filozoficznej między teistą a ateistą: trudno wyobrazić sobie, by teista, który faktycznie uważa, że stanowisko jego przeciwnika wynika z jego moralnych i duchowych deficytów, traktował poważnie jego argumenty i - szerzej - uznawał go za racjonalnego oponenta. 


\section{ZAKOŃCZENIE}

W koncepcji teistycznych znaków naturalnych Charles S. Evans zwraca uwagę na rolę pewnych specyficznych doświadczeń i własności świata w wytwarzaniu podstawowych przekonań teistycznych. Próbuje pokazać, w jaki sposób TZN mogą dostarczać naturalnej wiedzy o Bogu. Z projektem tym wiąże się szereg założeń dotyczących Boga i jego intencji: Bóg stworzył świat i pragnie być poznany przez swoje stworzenia, dlatego umieścił w rzeczywistości niementalnej i w ludzkim doświadczeniu łatwo dostępne „znaki” swojej obecności i wyposażył ludzi w dyspozycję do ich odczytywania. Ponieważ Bóg ceni ludzką wolność, sprawił, że znaki nie są jednoznaczne, dzięki czemu nikt nie jest przymuszony do uznania jego istnienia. Sądzę, że Evans nie wyjaśnia zadowalająco, dlaczego TZN są niejednoznaczne. Problemy dla koncepcji TZN stwarza także istnienie pewnych doświadczeń, które można potraktować jako „ateistyczne znaki naturalne”. Obecność takich systematycznie zwodzących doświadczeń w świecie stworzonym przez Boga jest racją za hipotezą, że Bóg ten jest zwodzicielem.

\section{REFERENCJE}

ADAMS, Sarah, i Jon RoBSON. 2016. „Does absence make atheistic belief grow stronger?” International Journal for Philosophy of Religion 79: 49-68. DOI: 10.1007/s11153-015-9532-3.

Dostojewski, Fiodor. 1913. Bracia Karamazow. Przełożyła Barbara Beaupré. Warszawa: Biblioteka Dzieł Wyborowych.

Evans, Charles S. 2010. Natural Signs and Knowledge of God. A New Look at Theistic Arguments. New York: Oxford University Press.

Evans, C[harles] S. 2011. „Religious Experience and the Question of Whether Belief in God Requires Evidence". W: Evidence and Religious Belief. Red. Kelly James Clark i Raymond J. VanArragon, 37-51. New York: Oxford University Press.

GALEWICZ, Włodzimierz. 1996. „Williama Jamesa spór z agnostycyzmem”. W: William JameS. Prawo do wiary. Przełożył Adam Grobler, 7-33. Kraków: Znak.

Gellman, Jerome. 1992. „A New Look at the Problem of Evil”. Faith and Philosophy 9, 2: $210-216$.

KarteZJusZ. 2006 [1647]. Medytacje o filozofii pierwszej. Przełożył Jan Hartman. Kraków: Wydawnictwo Zielona Sowa.

Plantinga, Alvin. 2000. Warranted Christian Belief. New York: Oxford University Press.

RucZAJ, Stanisław. 2017. „Doświadczenie zła jako racja dla ateizmu (analiza koncepcji Jerome’a I. Gellmana)". Racjonalia 7: 7-20. DOI: http://dx.doi.org/10.15633/r.2441.

SCHELlenberg, John. 2015. The Hiddenness Argument: Philosophy's New Challenge to Belief in God. Oxford: Oxford University Press.

West, Ryan, i Adam C. Pelser. 2015. „Perceiving God through Natural Beauty”. Faith and Philosophy 32, 3: 293-312. DOI: 10.5840/faithphil20157743. 


\title{
ZNAKI BOSKIEJ RZECZYWISTOŚCI: \\ INTERPRETACJA I KRYTYKA KONCEPCJI TEISTYCZNYCH ZNAKÓW \\ NATURALNYCH CHARLESA S. EVANSA
}

\begin{abstract}
Streszczenie
Celem artykułu jest interpretacja i krytyka koncepcji teistycznych znaków naturalnych (TZN), przedstawionej przez Charlesa S. Evansa. TZN to charakterystyczne doświadczenia lub własności świata, które sprawiają, że jednostka, która się z nimi zetknie, formuje pewne podstawowe, uzasadnione przekonania o istnieniu Boga $\mathrm{i}$ jego naturze. $\mathrm{W}$ artykule proponuję dwie interpretacje tego, jak funkcjonują TZN, odwołujące się do kategorii percepcji i pośredniej identyfikacji percepcyjnej. Przedstawiam także dwa argumenty krytyczne wobec koncepcji TZN. Po pierwsze, wskazuję, że nie wyjaśnia ona zadowalająco, dlaczego TZN są niejednoznaczne, tj., mogą być odczytywane na różne sposoby. Po drugie, zauważam, że pewne doświadczenia można potraktować jako ,ateistyczne znaki naturalne”. Istnienie takich doświadczeń daje rację do przypuszczenia, że Bóg jest zwodzicielem.
\end{abstract}

\section{SIGNS OF GOD'S PRESENCE: \\ CHARLES S. EVANS' THEORY OF THEISTIC NATURAL SIGNS - AN INTERPRETATION AND A CRITIQUE}

S u m m a ry

The aim of this paper is to interpret and criticize the theory of theistic natural signs (TNS), formulated by Charles S. Evans. TNS are characteristic experiences or features of the world which cause the person who encounters them to form certain basic beliefs about the existence and nature of God. I propose two interpretations of how TNS work, using the categories of perception and indirect perceptual recognition. I also present two arguments against the theory of TNS. First, I point out that the theory does not explain adequately why TNS are ambiguous, i.e., can be read in different ways. Second, I observe that certain experiences may be taken to be ,atheistic natural signs". Their existence gives one a reason to suspect that God is a deceiver.

Słowa kluczowe: filozofia religii; przekonania religijne; teistyczne znaki naturalne; Bóg; wiara i racjonalność.

Key words: philosophy of religion; religious beliefs; theistic natural signs; God; faith and rationality.

Information about Author: StanisŁaw Ruczaj, PhD — address for correspondence - e-mail: stanislaw.ruczaj@gmail.com; https://orcid.org/0000-0003-4115-376X. 